\title{
Myth or Substance: An examination of altruism as the basis of volunteer tourism
}

\author{
Alexandra Coghlan, Tourism Program, James Cook University, \\ Cairns, Australia
}

David Fennell, Brock University, Ontario, Canada

\begin{abstract}
Altruism is commonly associated with volunteer tourism as a motivational force for participants and a key factor in their on-site experiences. In this paper we seek a better understanding of the term altruism, and how it applies to the volunteer tourism sector. By applying altruism models that include outcomes of helping defined as both instrumental and ultimate goals, we review the volunteer tourism literature to look for egoistic and altruistic goals. Specifically, we examine volunteer tourists' motivations as well as experiences and benefits as outlined in 43 academic papers. The results suggest that, while volunteer tourists may behave in an altruistic manner, personal benefits derived from the experience by and large dominate the experience. It would appear that volunteer tourism represents a form of social egoism, which depending on the management of the volunteer tourists, and the goals and implementation of the project's goals, will indeed benefit local environments and communities. To move the debate forward, we suggest that the market forces as applied to the volunteer tourism sector may be examined, and other terms such as Eudaimonia be used to explain the pluralistic motivations, desires, and roles of volunteer tourists.
\end{abstract}

KEY WORDS: volunteer tourism, motivations, experiences, benefits, altruism

\section{Introduction}

Until recently, volunteer tourism, defined as ideologically sound travel experiences that contribute to the natural, economic, social and cultural environment' (Wearing, 2004: 218), has been guided almost exclusively by an 
altruistic ethic. This means that those who devote their time, money, and other costs to volunteer in tourism do so only for the benefit of those who are in need. In this regard, some theorists have gone so far as to call volunteer tourism 'altruistic tourism' (Mustonen, 2005, 2007; Singh \& Singh, 2004). The issue of altruism in volunteer tourism arises from its apparent moral superiority over other forms of travel, becoming the poster child of sustainable tourism (Lyons \& Wearing, 2008b) and representative of what Poon (1993) has described as 'new tourism', including concern for one's effects on other cultures as well as on the natural environment (see Broad, 2003; Gray \& Campbell, 2007; Simpson, 2004; Uriely, Reichel, \& Ron, 2003, who take a more inclusive stance on volunteer tourism).

We challenge the foregoing mindset by reviewing the meanings ascribed to the term altruism and argue that there may be just as much benefit afforded to the volunteer tourist actor as there is to the recipient. This challenge rests on more recent work, which has highlighted the need for further investigation into the motivational spectrum of volunteer tourists. For example, Fennell (2006a) argues that there are perhaps as many selfish reasons for travelling as a volunteer tourist as there are altruistic ones. This premise rests on supporting evidence from the field, including work by Myers (2003), who observes that he has seldom met a volunteer in the conservation field who has not sought some personal reward from their conservation efforts. Yet, there appears to be little evidence to suggest that this view has penetrated the mainstream literature, with the notable exception of Lyons and Wearing's new book on the subject (2008a), in which the editors and some contributing authors (e.g., McGehee \& Andereck, 2008) challenge belief in a symbiotic relationship between volunteering and tourism (Lyons \& Wearing, 2008b: 6).

The inconsistency in the volunteer tourism literature between the altruistic motivations ascribed to participants and their search for personal benefits may stem from a misunderstanding or misuse of the term altruism. In moving the debate forward, there appears to be scope for undertaking a review of current knowledge regarding altruism and the different streams of theory in tourism. Here we focus only on those organisations that offer tourists a conservation experience, such as Earthwatch and the Operation Wallecea Trust, many of which have a commercial branch within their organisations as well as supporting local NGOs and other not-for-profit organisations. Equally important is the use of an expanding base of research emerging in other fields that positions altruism as a fundamental element of human nature, that goes well beyond the context of volunteerism as it is used in tourism. In the end, we offer a different outlook on volunteer tourism based on the findings of this 
paper which suggest that volunteer tourism is a form of tourism that is primarily altruistic where costs (e.g., time, labour, and expense) to the volunteer outweigh the mostly personal benefits.

\section{Volunteer tourism and altruism: A closer look \\ Volunteer tourism}

While the origins of volunteer tourism have been traced back to volunteer organisations such as the US Peace Corps and Australian Volunteers Abroad (Wearing, 2004), Wight (1993) suggests that by the early 1990s consumers were deliberately seeking out an alternative travel experience that challenged traditional ethics, was enlightening, and incorporated a genuine sensitivity to the resource upon which it is based - thus paving the way for the emergence of a volunteer tourism sector. Since this time, volunteer tourism as both a research area and practice has gained momentum over the course of the past decade and a half. Evidence of this can be found in the intensification of research studies in this area, including the founding of a new research journal focused on volunteer tourism, as well as in the myriad different examples of travel opportunities that exist in a number of lesser developed country contexts. The growing popularity of the sector is illustrated by the guidebook Volunteer Vacations which offered 75 projects in 1987, and by 2003 offered 275 projects. The Lonely Planet has recently published a guide to volunteering overseas and the Green Volunteer guide is now in its fifth edition, printed in 2005, also listing 200 volunteer tourism organisations, primarily in Central and South America (for a review of volunteer tourism locations and project types, see Ellis, 2003; Callanan \& Thomas, 2005; Cousins, 2007).

One working definition of volunteer tourism is that it is a form of tourism that 'makes use of holiday-makers who volunteer to fund and work on social or conservation projects around the world and aims to provide sustainable alternative travel that can assist in community development, scientific research or ecological restoration' (Wearing, 2004: 217). While the boundaries of the volunteer tourism sector remain fluid, other theorists have added to this suggesting that volunteer tourism should last for less than a month using fixed dates; be advertised publicly; take paying tourists or volunteers; meet a tourist's special interest; be authentic and participatory in nature and provide opportunities to meet and work with like-minded people; contribute resources, such as labour and funding to aid the host organisation's activities in areas such as conservation or community development; and spawn new friendships, learning, and skill development (Broad, 2003; Ellis, 2003).

A concept that is foundational in the literature on volunteer tourism is motivation, which may be used to distinguish volunteer tourists from other 
similar types of travellers, like extreme ecotourists (Coghlan, 2006). Some authors even suggest that volunteer tourism is 'one of the most noble ways to travel' (Mustonen, 2005), motivated by altruism, and thus 'provides an opportunity for an individual to engage in an altruistic attempt to explore "self"' (Wearing, 2003; 242), and that "volunteer tourists differ from other tourists when the motivation basis is concerned. For them the main motivation is linked with an altruistic desire to volunteer' (Mustonen, 2005: 165). Ecotourists, in contrast, 'displayed a diversity of interests not confined to nature and were above all seeking a relaxing and interesting holiday . . . It must be kept in mind that ecotourists are often sophisticated, educated, but they are on holiday!' (Blamey, 1997: 30; see also Ryan, Hughes, \& Chirgwin, 2000).

\section{The nature of altruism}

On the nature of altruism, Barash (1982: 67) writes:

It is always nice to be nice to someone else, but it is hard to see this as adaptive. If helping another individual involves some cost to the helper, then the helper is hurting itself; that is, such behavior would be selected against compared to other, selfish behaviors - unless there are compensating benefits that render helping ultimately advantageous to the performer.

It does not make sense, biologically, to help others in a competitive environment, because this does little to secure our own survival. Yet there are seemingly countless examples, which, at face value, seem to indicate altruism in the animal world to counteract this perspective. William Hamilton (1964) provided theoretical guidance here through his theory of inclusive fitness. He said that we extend altruism to others as a function of relatedness. The closer one is related to us genetically, like a brother over a cousin, the more we are liable to help the former because he shares half of our genes, whereas the cousin shares one-eighth of our genes. Hamilton, according to Barash, recognised that parenting is a special case of genes looking out for themselves (in the metaphorical sense) in the bodies of a special type of individual: offspring. By helping those related to us, we help to preserve our own genetic base in the population.

But this theory, widely accepted by biologists, does not account for altruism between non-related individuals. We know that both in human and nonhuman populations cooperation (altruism) between members of a species is frequent under a number of conditions. Robert Trivers (1971) argued that altruism could take place between unrelated individuals if there is a chance 
that the altruist would derive a benefit from the recipient somewhere down the road - especially if this benefit outweighs the original cost of the altruistic act (this theory has been discussed in the context of tourism by Fennell [2006a, b] ). As such, reciprocal altruism is said to be a highly egoistical behaviour rather than an altruistic one because altruistic acts come packaged with the expectation of return favours down the road (Mayr, 1988), or by seeking approval, respect, or admiration benefits by fellow citizens (Alexander, 1987). In this regard Griffin (1997) argues that there is a troublesome step required in moving agents, who are genetically programmed to be selfish, to having concern for others. This is because we are programmed with a primitive form of egoism that is based on the care of a small number of what Griffin calls prudential values, including our own survival, advancement over others, and gratification (amongst others). We care for others, therefore, only to the degree that the well-being of these others affects our own (social egoism).

In contrast to the foregoing state, the psychologist Daniel Batson (1990) argues that our capacity for altruistic caring towards others is primarily a function of how much empathy (including sympathy, compassion, and tenderness) we have for the other. Batson contrasts egoism and altruism, as the two primary motivational states of why we choose to help others, with the goal of these actions (Table 1).

From Table 1 we see that the social egoist might strive to help another through instrumental means for the purpose of achieving the ultimate goal of benefiting oneself. By contrast, the altruist attempts to relieve the suffering of others as the ultimate goal, with benefits to the altruist emerging as unintended consequences of his or her actions. The degree to which we might argue for or against altruism or egoism is a function of the costs that we might incur in the transaction. For example, if we expend little energy or cost to help someone and this aid makes us especially happy, then we might

Table 1. Formal structure of the altruism question

\begin{tabular}{|l|c|c|}
\hline & \multicolumn{2}{|c|}{ Outcomes of helping } \\
\hline Explanations of why we help & $\begin{array}{c}\text { We relieve the other's } \\
\text { suffering }\end{array}$ & $\begin{array}{c}\text { And as a result we } \\
\text { receive self-benefits }\end{array}$ \\
\hline Egoistic account & Instrumental goal & Ultimate goal \\
\hline Altruistic account & Ultimate goal & $\begin{array}{c}\text { Unintended } \\
\text { consequences }\end{array}$ \\
\hline
\end{tabular}

Source: Batson (1990) 
after all be operating egoistically. However, if we go to great lengths to specifically make someone happy as the intended outcome, with little regard for our own happiness, than we may perhaps be regarded as more altruistic than in the first case. This is what Table 1 attempts to explain in the case of the unintended consequences of one's ultimate goal as an altruist (see Wallach \& Wallach, 1983).

What is not explicit in this table, however, is what Sober and Wilson (1998) argue as a key distinguishing characteristic of egoism and altruism. Egoism should be viewed as a monistic theory of motivation because it deals exclusively with ultimate desires of an individual - that all ultimate desires are self-directed. By contrast, altruism is decidedly a pluralistic theory of motivation because not all ultimate desires of the altruist are other-directed. In this regard, Sober and Wilson (1998: 228) argue:

The thesis of altruism, as we understand it, says that some people at least some of the time have the welfare of others as ends in themselves. This does not entail that most people are altruistic all the time, or that some people are altruistic most of the time, or that the altruism that people sometimes experience is especially strong.

Other social scientists have argued that the emotional basis of altruism lies in the fact that we are endowed with pro-social traits like shame, empathy, and guilt which lead to an immediate payoff for the altruist (Gintis, 2002). So we save babies from fires, and so on, not because of a long-term benefit but because of the immediate satisfaction of doing so. This immediate payoff also equates to the avoidance of guilt or shame, which would be a product of failing to act altruistically. Khalil's (2004) altercentric model on altruism is built according to this pro-social perspective, and makes use of Frank's (1988) theory of commitment, whereby agents view cheating as irrational because it erodes long-term stable relationships. It is the emotions that keep us on track in preventing us from making solely rational decisions in our own best interests based on minimising costs and maximising benefits.

\section{Merging volunteering, tourism, and altruism: An uneasy relationship?}

Wearing, Deville, and Lyons (2008: 63) remind us that volunteer tourism is in essence a form of leisure behaviour. Indeed a key characteristic of volunteer tourists is that they have deliberately chosen to combine volunteerism with leisure travel. Considering the core motivations for travel and tourism escape, relaxation, relationship enhancement, and self-development (Pearce 
\& Lee, 2005) - it would seem that tourism does not lend itself to deliberately or consciously decreasing the fitness of the tourist, but may alternatively allow for the type of social egoism described above. However, Uriely et al. (2003) describe volunteer tourism as an expression of the so-called 'other' postmodern tourism, with a search for the authentic and the experiential. It may be argued that the trend towards merging volunteerism and leisure, as a commodified product, is an expression of this postmodern mindset in accordance with the need to be green, the demand for new (niche) tourism products, and finally a packaging of experiences that makes tourists accessible to wider markets. Based on these trends, it is easy to see how a tourism product that combines travel, leisure, and conservation in an experiential setting has become popular. And commercial and non-profit organisations are quick to tap into this new trend. In one of the first books on the topic, Wearing (2003: 215) pointed out that 'by understanding the nature of the target market, tourism operators can alter marketing mix components according to the needs of an altruistically motivated consumer', demonstrating the attempt to market to the needs of volunteer tourists through effective product design. A number of authors have pointed to the ways in which organisations often promote their programmes using neocolonialist, or imperialist representations of the host communities rather than incorporating the voices of the communities (Wearing, 2001, cited in Raymond, 2008: 54; Simpson, 2004).

Certainly the literature suggests that the basis of environmentally based volunteer tourism products are charismatic mammals particularly carnivores, whales/dolphins, primates, and elephants, and that projects with the fastest uptake are in the tropics and involve hands-on work (Ellis, 2003; Cousins, 2007). In reviewing the promotional material of volunteer tourism organisations, Coghlan (2007) found that organisations commonly used images of animals, exotic landscapes, and local people to sell their trips, and that volunteer tourist testimonials that emphasise personal development of the participants, praise for the organisation, and opportunities to have fun were more commonly used than those that promote the 'worthiness' of the actual project.

To further this point, Gazley (2001: 5) believes that volunteer tourism organisations 'blatantly market the more personal benefits, such as costsavings and personal growth' and Simpson (2004) uses this example from VentureCo. to demonstrate the commodified volunteer tourism experiences that appeal to personal benefit-seeking:

Does the idea of travel to far off destinations appeal to you? How about the adventure of joining an expedition into the world's greatest mountain ranges? 
And I expect that you'd like to help a disadvantaged community and acquire new skills while working on an aid project ... At the same time you're probably thinking about how your Gap Year will fit into the broader picture, will it be something to impress future employers and how will it look on your CV?' (VentureCo., 2002, cited by Simpson, 2004: 684)

It would appear that volunteer tourism NGOs, commercial ventures, and government departments are promoting a much wider range of personal benefits than simply altruistic motivations designed to benefit the 'disadvantaged community'. Given that those responsible for marketing and creating the volunteer tourism sector (the practitioners) seem to have tapped into the pluralistic, personal-benefit seeking nature of volunteer tourism participants, it seems reasonable to ask how this is being reflected in the theoretical work that is flourishing on the sector, and draw some conclusions as to the nature and future directions of volunteer tourism.

\section{Methodology}

To examine the role altruism plays as an integral component that shapes volunteer tourism, the authors reviewed 44 key papers and book chapters on volunteer tourism spanning the last 15 years to the year 2008. The search engines, Ingenta Connect and Google Scholar were used to identify abstracts with a focus on volunteer (and participatory) tourism. Every effort was made to comprehensively cover the literature specific to volunteer tourism, including papers from the Special issue on the topic in Tourism and Recreation Research (ed. S. Wearing, 2003), the electronic journal E-Volunteerism; the books Volunteering as Leisure/Leisure as Volunteering; Volunteer Tourism: Experiences That Make a Difference; and the most recent book, Journeys of Discovery: International Case Studies in Volunteer Tourism, published in 2008. The authors are aware of a growing body of graduate research on this topic; however, for the purpose of this study, papers were limited to peer-reviewed publications.

The selected papers were limited to those that covered tourists (i.e., a 'person travelling to and staying in places outside their usual environment for not more than one consecutive year for leisure, business and other purposes' [United Nations World Tourism Organisation (UNWTO), 1995]) working on social and conservation projects around the world. The complete list of 44 articles examined in the study is provided in the Appendix, of which 34 were considered to shed light on the role of altruism in tourism, and 18 specifically used the term altruism; Table 2 briefly summarises the sample, method, and findings of these later papers based on their abstracts (i.e., the key points as chosen by the authors). 
Table 2. Summary of the sample, methods and findings of key volunteer tourism (VT) studies

\begin{tabular}{|c|c|}
\hline Study Author and Title & Summary of research topic and findings \\
\hline $\begin{array}{l}\text { Broad, S. (2003). } \\
\text { Living the Thai Life: A case study } \\
\text { of volunteer tourism at the } \\
\text { Gibbon Rehabilitation Project, } \\
\text { Thailand. }\end{array}$ & $\begin{array}{l}\text { Represents an ethnographic case study of volunteering } \\
\text { at a project in Thailand exploring the relationship } \\
\text { between volunteers, their volunteering experiences, and } \\
\text { the outcomes. The findings were that volunteers were } \\
\text { provided with substantial opportunities to make positive } \\
\text { contributions to wildlife conservation and were able to } \\
\text { go beyond superficial interactions with local residents, } \\
\text { immersing themselves in Thai culture. The experiences are } \\
\text { said to lead to benefits by contributing to personal growth } \\
\text { and changed view of the world. }\end{array}$ \\
\hline $\begin{array}{l}\text { Brown, S., \& Lehto, X. Y. (2005). } \\
\text { Travelling with a purpose: } \\
\text { Understanding the motives } \\
\text { and benefits of volunteer } \\
\text { vacationers. }\end{array}$ & $\begin{array}{l}\text { Examines the motivations of volunteer tourists using } \\
\text { interviews. Four themes emerged: cultural immersion, the } \\
\text { desire to give back, the camaraderie of the experience, } \\
\text { and family-time. The study is said to illustrate a good } \\
\text { example of cultivating peace through tourism. }\end{array}$ \\
\hline $\begin{array}{l}\text { Campbell, L. M., \& Smith, C. } \\
\text { (2006). } \\
\text { What makes them pay? Values } \\
\text { of volunteer tourists working for } \\
\text { sea turtle conservation. }\end{array}$ & $\begin{array}{l}\text { Examines the ways that volunteers value sea turtles at a } \\
\text { project in Costa Rica. The complexity of volunteer values } \\
\text { were explored using interviews of } 31 \text { volunteers. Results } \\
\text { indicated that volunteers hold multiple and complex } \\
\text { values for sea turtles, and these have implications for } \\
\text { understating human-environment relations. }\end{array}$ \\
\hline $\begin{array}{l}\text { Coghlan, A. (2006). Volunteer } \\
\text { tourism as an emerging trend } \\
\text { or an expansion of ecotourism? } \\
\text { A look at potential clients' } \\
\text { perceptions of volunteer } \\
\text { tourism organisations. }\end{array}$ & $\begin{array}{l}\text { Examines potential tourists' perceptions of VT } \\
\text { organisations using a multiple sorting procedure that asks } \\
\text { respondents to differentiate between VT organisations. } \\
\text { The results suggested that respondents distinguish } \\
\text { between organisations offering a volunteering experience } \\
\text { and a holiday experience. Also, respondents with a high } \\
\text { level of familiarity seek different benefits from their } \\
\text { experience. }\end{array}$ \\
\hline $\begin{array}{l}\text { Coghlan, A. (2007). Towards } \\
\text { an integrated image-based } \\
\text { typology of volunteer tourism } \\
\text { organisations. }\end{array}$ & $\begin{array}{l}\text { Identifies VT organisational images and suggests how } \\
\text { these images affect the expectations of volunteer tourists. } \\
\text { Using a content analysis of the promotional material } \\
\text { of VT organisations. From the results, four groups of VT } \\
\text { organisations were identified and labelled 'conservation } \\
\text { research expeditions','holiday conservation expeditions', } \\
\text { 'adventure conservation expeditions', and 'community } \\
\text { holiday expeditions'. }\end{array}$ \\
\hline
\end{tabular}




\begin{tabular}{|c|c|}
\hline Study Author and Title & Summary of research topic and findings \\
\hline $\begin{array}{l}\text { Cousins, J. A. (2007). The role of } \\
\text { UK-based conservation tourism } \\
\text { operators. }\end{array}$ & $\begin{array}{l}\text { Provides an insight into the UK conservation tourism } \\
\text { industry, examining the scale of the industry and } \\
\text { the diversity and practices of the organisations. It } \\
\text { suggests that as the industry expands further it will be } \\
\text { important for these organisations to keep the quality } \\
\text { of their conservation products high and the volunteer's } \\
\text { engagement with the nature deep and meaningful. }\end{array}$ \\
\hline $\begin{array}{l}\text { Ellis, C. (2003). Participatory } \\
\text { environmental research in } \\
\text { tourism: A global view. }\end{array}$ & $\begin{array}{l}\text { Examines the growing field of participatory environmental } \\
\text { research, identified as a holiday choice by travellers and } \\
\text { a source of funding for researchers, and examines the } \\
\text { constraints and issues and identifies how the partnerships } \\
\text { and operating structures impact on the resulting benefits } \\
\text { and costs. }\end{array}$ \\
\hline $\begin{array}{l}\text { Gazley, B. (2001). Volunteer } \\
\text { vacations and what research } \\
\text { can tell us about them. }\end{array}$ & $\begin{array}{l}\text { Describes VT in the context of US national volunteering } \\
\text { trends and research into volunteer programs and focuses } \\
\text { on how the needs of the volunteer vacationer have } \\
\text { required organisations to change their internal climates, } \\
\text { programs, and recruitment. }\end{array}$ \\
\hline $\begin{array}{l}\text { Gray, N. J., \& Campbell, L. M. } \\
\text { (2007). } \\
\text { A decommodified experience? } \\
\text { Exploring aesthetic, economic, } \\
\text { and ethical values for volunteer } \\
\text { ecotourism in Costa Rica. }\end{array}$ & $\begin{array}{l}\text { Using a case study of VT in Costa Rica, the study } \\
\text { investigates the ideal of VT as a decommodified } \\
\text { ecotourism product. Perceptions of VT were explored } \\
\text { through interviews with } 36 \text { stakeholders. While their views } \\
\text { were generally positive, subtle but important differences } \\
\text { existed. These were analysed in terms of aesthetic and } \\
\text { economic values. }\end{array}$ \\
\hline $\begin{array}{l}\text { Halpenny, E. A., \& Caissie, L. T. } \\
\text { (2003). Volunteering on nature } \\
\text { conservation projects: Volunteer } \\
\text { experiences. }\end{array}$ & $\begin{array}{l}\text { Describes the experiences of volunteers participating } \\
\text { in 3-to-17-day conservation vacations in Canada, and in } \\
\text { particular describes their attitudes and values regarding } \\
\text { nature. The authors found three types: egoistic concerns, } \\
\text { altruistic concerns, and to a lesser extent, biocentric } \\
\text { concerns, and concluded that the experience generally } \\
\text { failed to change the volunteers' perceptions of nature } \\
\text { from an external phenomenon to an internal one, } \\
\text { with implications for pro-environmental attitudes and } \\
\text { behaviours. }\end{array}$ \\
\hline $\begin{array}{l}\text { McGehee, N., \& Santos, C. A. } \\
\text { (2005). } \\
\text { Social change, discourse and } \\
\text { volunteer tourism. }\end{array}$ & $\begin{array}{l}\text { Explores VT using theories of social movements and } \\
\text { found that participation in VT has a positive effect on both } \\
\text { intended post-trip social movement activities and support } \\
\text { for activism. The implications for providing network ties } \\
\text { and/or consciousness-raising experiences both during } \\
\text { and after the experience are discussed. }\end{array}$ \\
\hline
\end{tabular}




\begin{tabular}{|c|c|}
\hline Study Author and Title & Summary of research topic and findings \\
\hline $\begin{array}{l}\text { McGehee, N. (2002). Alternative } \\
\text { tourism and social movements. }\end{array}$ & $\begin{array}{l}\text { Develops a model that draws on social-psychological and } \\
\text { resource mobilisation theories to explain changes in social } \\
\text { movement participation among Earthwatch Expedition } \\
\text { volunteers. Using pre- and post-trip surveys, found that as } \\
\text { a consequence of social networks established during an } \\
\text { expedition, participation in an expedition had a positive } \\
\text { effect on social movement activities. }\end{array}$ \\
\hline $\begin{array}{l}\text { McGehee, N. \& Norman, W. } \\
\text { (2002). } \\
\text { Alternative tourism as Impetus } \\
\text { for Consciousness Raising }\end{array}$ & $\begin{array}{l}\text { This study develops and tests a theoretical model, drawing } \\
\text { on social-psychological perspectives of social movement } \\
\text { theory to explain changes in consciousness among } \\
\text { Earthwatch expedition volunteers, using pre- and post- } \\
\text { trip surveys of over } 350 \text { Earthwatch expedition volunteers. } \\
\text { The results reveal that both network ties established } \\
\text { during an Earthwatch expedition and perceived self- } \\
\text { efficacy gains during an Earthwatch expedition positively } \\
\text { and significantly influence consciousness-raising. }\end{array}$ \\
\hline $\begin{array}{l}\text { Mclntosh, A. J., \& A. Zahra, A. } \\
\text { ( } 2007) \text {. } \\
\text { A cultural encounter through } \\
\text { volunteer tourism: Towards the } \\
\text { ideals of sustainable tourism. }\end{array}$ & $\begin{array}{l}\text { Examines the nexus between VT and cultural tourism in } \\
\text { the search for alternative and sustainable experiences. } \\
\text { Uses qualitative research to examine the experiences of } 12 \\
\text { Australian visitors volunteering in a Māori community. The } \\
\text { experience provided a mutually beneficial engagement, } \\
\text { with a rich and genuine cultural content, which reflected } \\
\text { modern Maori life in New Zealand. }\end{array}$ \\
\hline $\begin{array}{l}\text { Mustonen, P. (2005). Volunteer } \\
\text { tourism: Postmodern } \\
\text { pilgrimage. }\end{array}$ & $\begin{array}{l}\text { Examines VT in the context of postmodern tourism, and } \\
\text { highlights the differences between it and other forms of } \\
\text { postmodern tourism, arguing that these differences are } \\
\text { connected with traditional pilgrimage; volunteer tourists } \\
\text { are said to follow their altruistic motivations, and reach } \\
\text { their aspiration of a sacred consciousness. }\end{array}$ \\
\hline $\begin{array}{l}\text { Simpson, K. (2004). 'Doing } \\
\text { Development': The gap year, } \\
\text { volunteer tourists and a popular } \\
\text { practice of development. }\end{array}$ & $\begin{array}{l}\text { Investigates the phenomenon of third-world VT } \\
\text { programmes which seek to combine the hedonism of } \\
\text { tourism with the altruism of development work. The } \\
\text { paper seeks to critique the construction of this public face } \\
\text { of development, while also asking, from a pedagogical } \\
\text { perspective, what travelling participants learn about the } \\
\text { 'others' they encounter. }\end{array}$ \\
\hline
\end{tabular}




\begin{tabular}{|l|l|}
\hline Study Author and Title & Summary of research topic and findings \\
\hline $\begin{array}{l}\text { Uriely, N., Reichel, A., \& Ron, A. } \\
\text { (2003). }\end{array}$ Volunteering in tourism: & $\begin{array}{l}\text { Suggests that VT is an expression of the so-called other } \\
\text { postmodern tourism and argues that the notion of } \\
\text { volunteering needs to be expanded beyond volunteering } \\
\text { guests and include hosts who volunteer in the local } \\
\text { tourism industry. It proposes that in addition to VT } \\
\text { as self-development, volunteers in tourism may also } \\
\text { enhance their self-image and use their volunteering for } \\
\text { self-presentation purposes and finally argues that the } \\
\text { nature and results of the host-guest encounter may vary } \\
\text { according to the different settings of volunteering in } \\
\text { tourism. }\end{array}$ \\
\hline $\begin{array}{l}\text { Weiler, B., \& Richins, H. (1995). } \\
\text { Extreme, extravagant and elite: } \\
\text { A profile of ecotourists on } \\
\text { Earthwatch expeditions. }\end{array}$ & $\begin{array}{l}\text { Analyses the promotional material of Earthwatch } \\
\text { expeditions, the written comments of its volunteers, } \\
\text { and a survey of } 245 \text { of its volunteers. The participants } \\
\text { are said to be extreme ecotourists, wanting not only to } \\
\text { be environmentally responsible but also to enhance the } \\
\text { environment visited, with intense and active levels of } \\
\text { interaction with the environment. }\end{array}$ \\
\hline
\end{tabular}

A manifest content analysis was used to determine the role of altruism in volunteer tourism according to the use of the term by Weber (1990): content analysis, or the 'rigorous examination of communications' (Babbie, 1986: 45), can be either manifest (the most common) or latent in its design. Manifest focuses on the actual recorded message of the communication, that is what is actually written in the document, while latent refers to the underlying meaning of these communications, that is what might have been said but is not actually said. The recording unit may be a word, sense of a word, sentence, theme, paragraph, or the entire text itself (Weber, 1990). In this study we followed the scheme identified by Weber (1990), which included the following process: define the categories to be coded, test coding on a sample of text, assess reliability, revise the coding rules, code again a sample of text, code all the text, and finally assess the reliability. Two coders were used in this study with an inter-rater reliability factor of $94 \%$.

The analysis of these papers yielded two main demand-side volunteer tourism themes: volunteer tourist motivations, and experiences and benefits of participation. To provide a framework for review, Batson's structure of the altruism question is used and as each paper is reviewed, the goals and consequences of participating in a volunteer tourism project were highlighted, according to the account provided by the author(s) of the study. This paper therefore follows a dichotomous structure of egoistic and altruistic 
accounts found in the existing literature, examining firstly, volunteer tourists' motivations and, secondly, experiences and benefits.

\section{Results}

Using Batson's structure of altruism, we examine, first, the motivations of volunteer tourists (explanations of why we help) and, second, the descriptions of their experiences and the benefits they received from participating (intended and unintended outcomes of helping).

\section{Why volunteers help: Volunteer tourists' motivations and goals}

Understanding why volunteer tourists wish to help, that is their instrumental and ultimate goals, will provide the greatest wealth of information on why tourists might volunteer. We have already suggested that many research papers support the notion that volunteer tourists are motivated to join a project through altruism. In reviewing the 44 papers found on volunteer tourists, 21 papers discuss motivations and 18 of those specifically mention altruism as a motivation. A closer look at these papers indicates that the authors also reveal a number of (ultimate) goals that include self-benefits (Table 3).

While it is not always easy to distinguish between the respondents' ultimate and instrumental goals, some authors provide clear indications regarding respondents' primary and secondary motivations; so, for instance, Halpenny and Caissie (2003: 30) say that the volunteer tourists' primary motive was always to have fun, followed by additional factors such as skills and knowledge acquisition for career advancement or to experience a new challenge. Another example is provided by a respondent in McIntosh and Zahra's (2007: 546) study, who says: 'My main motivation was to give, because I know in giving you are happy. I saw and spoke to others who'd done this type of project and I could see it was so rewarding I wanted to do something like this.' Table 3 offers a snapshot of some of the altruistic and egoistic reasons for helping as cited by the authors studying volunteer tourist motivations. In most cases, the studies have identified both altruistic and egoistic motivations within the same sample, highlighting the complexity of the issue.

The idea that volunteer tourism balances the search for personal benefits and altruism is clearly present, if not openly acknowledged in many of the 21 studies on volunteer tourism motivations. Soderman and Snead (2008) stated that volunteers analyse the costs and benefits of activities offered, and go so far as to provide a list of top 10 volunteer tourist motivations, such as fulfilling a dream, broadening horizons, influence of family and peers, experience for the future, and desire for more than just travel, as well as reputation of the organisation and the safety that it offered. They provide examples such as 
Table 3. Review of studies of volunteer tourists' goals based on Batson's explanations of why people help others

\begin{tabular}{|c|c|}
\hline Authors and Subject & Goals \\
\hline Mustonen (2005) India & Egoistic: value change and self-actualisation \\
\hline \multirow{2}{*}{$\begin{array}{l}\text { Mclntosh \& Zahra (2007) } \\
\text { Australian volunteers in a Māori } \\
\text { community }\end{array}$} & Altruistic: to give, experience a service project \\
\hline & Egoistic: self-development \\
\hline \multirow[t]{2}{*}{$\begin{array}{l}\text { Weiler \& Richins (1995) } \\
\text { Earthwatch Australia Volunteers }\end{array}$} & $\begin{array}{l}\text { Altruistic: do something meaningful and help the } \\
\text { researcher }\end{array}$ \\
\hline & Egoistic: learn new things and be challenged \\
\hline \multirow{2}{*}{$\begin{array}{l}\text { Wearing (2003) } \\
\text { Volunteer tourists in Costa Rica }\end{array}$} & Altruistic: save the environment \\
\hline & Egoistic: explore the self \\
\hline \multirow{2}{*}{$\begin{array}{l}\text { Broad (2003) } \\
\text { Tourists at a Gibbon } \\
\text { rehabilitation centre in Thailand }\end{array}$} & $\begin{array}{l}\text { Altruistic: Secondary motivations: desire to help wildlife/ } \\
\text { conservation }\end{array}$ \\
\hline & $\begin{array}{l}\text { Egoistic: Primary motivation: travel, as well as to gain } \\
\text { experience relevant to their studies and future career plans. }\end{array}$ \\
\hline \multirow{2}{*}{$\begin{array}{l}\text { Halpenny \& Caissie (2003) } \\
\text { Volunteer tourists in Canada's } \\
\text { Volunteer for Nature program }\end{array}$} & Altruistic: Secondary motivation: save the environment \\
\hline & $\begin{array}{l}\text { Egoistic: Primary motivation: have fun, followed by } \\
\text { additional factors such as skills and knowledge acquisition } \\
\text { for career advancement or to experience a new challenge }\end{array}$ \\
\hline \multirow{2}{*}{$\begin{array}{l}\text { Brown \& Lehto (2005) } \\
\text { Focus group of ex-volunteer } \\
\text { tourists }\end{array}$} & Altruistic: give back and make a difference \\
\hline & $\begin{array}{l}\text { Egoistic: in-depth cultural immersion, camaraderie, and } \\
\text { educational and bonding opportunities }\end{array}$ \\
\hline
\end{tabular}

the following that illustrated personal benefits that might motivate tourists to choose a volunteer tourism program:

If you want to get paid to do teaching abroad, you need to have qualifications ... whereas if you are volunteering ... it allows you to have a similar experience without the need to have done as much in the past and have any qualifications. (Soderman \& Snead, 2008: 124)

Only four studies found in this literature review do not mention the term altruism as a motivation for their respondents. These studies include McGehee and Norman (2002), who state that individuals participated in Earthwatch programs because they wished to expand their activist identities into their leisure travel, and Gazley (2001) who suggests that traditional travel motivations such as fun, excitement, adventure, and learning are likely to apply 
to volunteer vacationers, and most are in search of opportunities to develop interpersonal skills, save money, and meet people from other cultures and like-minded people.

In addition, Coghlan's own study of volunteer tourists from five different organisations found that their most important motivations were to experience new and different things, have a good time, take part in a rare opportunity, and explore new places. Using an open-ended question, Coghlan's (2005) study found 12 motivational themes. These themes were to 'visit otherwise inaccessible places', 'because I enjoyed past trips with this organisation', 'visit new places and travel', 'have an adventure or experience new things', 'meet new people or people with similar values', 'increase my knowledge of the environment', 'because I am interested in the flora and/or fauna', 'help the researcher / be involved in conservation/work on a worthwhile project', 'for the photographic opportunities', 'for the research/science', 'to increase my practical skills' (e.g., diving, sailing, surveying, trapping) and 'for the adventure activities' (e.g., trekking, sailing, diving).

\section{Outcomes of helping: Volunteer tourists' experiences and benefits}

While the literature on volunteer tourism motivations indicates that there are, at the very least, several layers of goals that may in some cases indicate egoistic accounts and self-beneficial ultimate goals, suggesting the occurrence of social egoism, studies of experiences also reveal self-benefits that emerge as (un)intended consequences of participation (e.g., Mustonen, 2007). Indeed, on balance, references to their experiences tend to focus more on the social and fun aspects of the trip and project. A respondent in Soderman and Snead's study (2008: 124) says of his experience: 'It is also a fun experience for me. If you want to help other people, you can just give money to Oxfam or whatever! I'm sure that's more useful than me spending five grand on this!' while Brown and Lehto (2005: 490) provide this example from one of their respondents: 'I think the vacation was fun! I just think it [the volunteer experience] was another element to bring to it that was even neater.'

In another example, Broad (2003: 67) quotes her respondents as saying the following about their experiences: 'The strongest memories are of the other volunteers; some of them became good friends and times out with the volunteers, like the beach parties or Christmas Day and just relaxing after work and sitting and talking all night.'

In an initial study of volunteer tourists working with sea turtles in Costa Rica, Campbell and Smith (2006) used interviews to analyse the values that volunteers place on the turtles and their experience with the turtles. They found that volunteers placed more emphasis on the scientific, aesthetic, 
humanistic, and experiential value of the turtles. In a later study, Gray and Campbell (2007) found that the best experiences for their respondents centred around the interactions with the sea turtles, social interaction with volunteer and local residence, cultural/language exchange, education, and relaxation.

This lends support to Coghlan's (2005) findings from volunteer diaries that the volunteer tourism experience focused on seeing and learning about the animals and plants, the social aspects of the trip, the work and opportunities to help the researcher, discovering a new place, personal discoveries, and new experiences, and that a successful volunteer tourism expedition contained a balance of opportunities to learn, experience new and different things, have fun, and contribute to a worthwhile project. Excerpts from some of the volunteer tourists' diary entries illustrates the role of experiencing new and different things, as well as personal development in volunteer tourism:

By far this was one of the best days of my life. Just the crow's nest, and watching the dolphins play across the bow then getting in the zodiac and getting so close to the fin whales. I have never experienced anything like it climbing to the crow's nest was hands-down the best experience of the day. It was at the same time the most exhilarating experience of my life. My fear of heights has kept me from doing a lot, but I was determined to do this. It was all worth it, the view was breathtaking and the feeling was indescribable.

The personal benefits are particularly apparent in statements such as this one also from Coghlan (2005):

Finding that warm, humidity-free temperatures improved my stiff joints and itchy eyes, finding that my hearing was more acute than that of many fellow travellers (particularly helpful for bird calls). Finding that I could walk as far and as fast as most. Feeling hopeful that I can undertake further such expeditions.

In a similar vein, past research has identified the benefits that participants derived from their experience (Broad, 2003; Brown \& Lehto, 2005; Lepp, 2008; McGehee \& Santos, 2005; McIntosh \& Zahra, 2007; Raymond, 2008; Ruhanen, Cooper, \& Fayos-Sola, 2008; Simpson, 2004; Wearing, 2003). These focus on three areas: (i) personal development and self-fulfilment, particularly a great sense of empowerment and independence, increasing selfawareness, and a spiritual development by reflecting on Western values; (ii) knowledge gain and increased skills; and (iii) enhanced interpersonal relations and social networks. In some cases it would appear that these three benefits 
come together as a change of career path for the participant (Broad, 2003; Brown \& Lehto, 2005; McGehee \& Santos, 2005). For others, as described by Gazley (2001), the volunteer tourism experience offers benefits of a kind that cannot always be purchased, for instance seeing the results of (hard) work, and connecting with other people. For most, however, the volunteer tourism experience 'is about blending good hard work and volunteering with some fun activities wrapped around it, and knowing that there will be some pretty neat people doing the same thing' (Brown \& Lehto, 2005: 489).

\section{Discussion and conclusion}

Given the evidence presented above, the role that altruism might play in volunteer tourism is unclear. Certainly, it is a fallacy to say that volunteer tourists are completely altruistic, although it might be true that they behave in an altruistic manner and have some altruistic-like motivations. A couple of recent papers suggest that volunteer tourism represents a form of reciprocal altruism as "it is clear that volunteering is not just about "doing good" for others but it is also about doing good for self, about reciprocal altruism' (Matthews, 2008: 111; Soderman \& Snead, 2008: 123). On balance, however, it would appear that volunteer tourism represents a form of social egoism, engaging participants to help others through instrumental means but for the purpose of achieving the ultimate goal of benefiting oneself. In fact this is arguably the key to the success of volunteer tourism as an emerging sector, and its growing popularity. Perhaps the most that can be said about volunteer tourists is that they are, at least in theory, contributing to the social and natural well-being of their host environment, through the instrumental means of project participation. Although this too is highly contested within the literature on volunteer tourism, with published papers supporting both arguments (c.f. Simpson, 2004; Callanan \& Thomas, 2005; McGehee, 2001).

To move beyond the altruism debate in volunteer tourism we might consider other theories; here we propose another useful term to be applied to volunteer tourism, in such cases where authors wish to highlight its more worthy and noble characteristics that distinguish it from mass tourism - the Greek term Eudaimonia. Although few authors have so far considered Eudaimonia in a tourism context, with notable exceptions from Fennell (2006a), Fennell and Malloy (2007), Pearce (in press) and de Botton (2002), this form of satisfaction may be an appropriate one to consider in certain specialist tourism sectors such as volunteer tourism. As a philosophy, it argues that true happiness is found in the expression of virtue, in doing what is worth doing, and leads to spiritual and personal fulfilment and the actualisation of human potentials. It is most commonly associated with psychological 
concepts such as intrinsic motivation and personal expressiveness (concepts which have been applied to both tourism [e.g. Fielding, Pearce, \& Hughes, 1992] or in volunteering [e.g. Bonjean, Markham, \& Macken, 1994]), and is a fundamental source of well-being and life satisfaction.

One facet of volunteer tourism that must not be ignored is that hedonistic experiences are also sought out, as has been argued throughout this paper. Tourism is primarily a consumptive experience that is increasingly commodified and packaged. In fact, Mustonen (2005) makes a very valid point concerning the shifting roles of volunteer tourists, who may go from being tourists seeking out pleasure, relaxation, stimulation, and so forth during part of their trip before, after, or during their volunteer tourism experience, when many younger tourists shift roles between volunteer tourist and backpacker, and engage in leisure travel, sightseeing, adventure tourism, souvenir shopping, partying, and so forth.

While proponents of volunteer tourism advocate it as a form of moral, sustainable tourism, we are repeatedly warned that volunteer tourism must strive to avoid becoming a form of green imperialism, where volunteers want to see their own environmental values spread amongst local people, which Gray and Campbell (2007) argue undermines Wearing's (2001) argument that volunteer tourism privileges local values and enables genuine exchange. Mowforth and Munt (2008) discuss volunteer tourism as a form of alternative tourism but caution that it may be no more ethically superior then mass tourism. This may be the case, according to Scheyvens (2002), because volunteer initiatives may have little regard for the interests of the local people and communities in which they are situated. Gray and Campbell (2007: 479) conclude more research into the comparison of meanings, perception of impacts, and measured impacts as they warn that:

if impacts are to be planned for and mitigated (if negative) or enhanced (if positive) in order to sustain volunteer (eco)tourism projects over the longterm, then an uncritical assumption of that volunteer tourism is inherently special and different from other forms of (eco)tourism will likely prove to be problematic.

In their recent work, Lyons and Wearing (2008a, b) argue that as NGOs begin to develop partnerships with corporate entities, they run the risk of losing sight of their core activity of supporting local communities at all costs and instead become engaged in the process of commodification of alternative forms of tourism, including volunteer tourism. These authors question whether a philosophy and practice of volunteer tourism that extends beyond 
market priorities can be sustained in the global tourism marketplace, pointing out that ecotourism has not been able to resist the global commodification in international tourist markets. They believe that we can already find evidence that the commodification of volunteer tourism is occurring with large tour operators competing for a share of this new market (p. 153c).

The question is not settled amongst practitioners and academics, pointing towards a need for more research into volunteer tourism. Views arguing that volunteer tourism represents the truest form of alternative, sustainable, and ethical tourism are countered with equally strong arguments that volunteer tourist projects lack critical engagement between the participants and their surroundings. This paper has demonstrated that the motivations of volunteer tourists are not simply altruistic but also egoistic. Even those motivations that have been shown to be altruistic should be scrutinised more fully through, for example, the work of Sober and Wilson (1998) who argued that altruism is a pluralistic theory of motivation as not all ultimate desires of the altruist are other-directed. As the volunteer tourism sector further develops, it will help to take a pragmatic view that tourism as an industry will be subject to market forces that will always shape it to a lesser or larger extent - and also that what has been masked as altruism in volunteer tourism is worth exploring in far greater detail.

\section{References}

Alexander, R. D. (1987). Darwinism and human affairs. Seattle: University of Washington Press.

Babbie, E. (1986). The practice of social research (4th ed.). Belmont, CA: Wadsworth Publishing.

Barash, D.P (1982). Sociobiology and Behavior, 2nd ed. New York: Elsevier.

Batson, C. D. (1990). How social an animal? The human capacity for caring. American Psychologist, 45(3), 336-346.

Blamey, R. K. (1997). Ecotourism: The search for an operational definition. Journal of Sustainable Tourism, 5(2), 109-130.

Bonjean, C. M., W. T. Markham, \& Macken, P. O. (1994). Measuring self-expression in volunteer organisations: A theory-based questionnaire. Journal of Applied Behavioural Science, 30(4), 487-514.

Broad, S. (2003). Living the Thai Life: A case study of volunteer tourism at the Gibbon Rehabilitation Project, Thailand. Tourism Recreation Research, 28(3), 63-72.

Brown, S., \& Lehto, X. Y. (2005). Traveling with a purpose: Understanding the motives and benefits of volunteer vacationers. Current Issues of Tourism, 8(6), 479-496.

Callanan, T., \& Thomas, S. (2005). Volunteer tourism: Deconstructing volunteer activities within a dynamic environment. In M. Novelli (Ed.). Niche tourism: 
Contemporary issues, trends and cases. Oxford: Butterworth-Heiniman Elsevier.

Campbell, L. M., \& Smith, C. (2006). What makes them pay? Values of volunteer tourists working for sea turtle conservation. Environ Management, 38(1), 373-388.

Coghlan, A. (2005). Towards an understanding of the volunteer tourism experience. Unpublished PhD dissertation, James Cook University, Townsville, Queensland.

Coghlan, A. (2006). Volunteer tourism as an emerging trend or an expansion of ecotourism? A look at potential clients' perceptions of volunteer tourism organisations. International journal of Nonprofit and Voluntary Sector, 11, 225-237.

Coghlan, A. (2007). Towards an integrated image-based typology of volunteer tourism organisations. Journal of Sustainable Tourism, 15(3), 267-287.

Cousins, J. A. (2007). The role of UK-based conservation tourism operators. Tourism Management, 28,1020-1030.

de Botton, A. (2002). The art of travel. New York: Hamish Hamilton.

Ellis, C. (2003). Participatory environmental research in tourism: A global view. Tourism Recreation Research, 28, 45-55.

Fennell, D. A. (2006a). Tourism ethics. Clevedon, UK: Channel View Publications.

Fennell, D. A. (2006b). Evolution in tourism: The theory of reciprocal altruism and tourist-host interactions. Current Issues in Tourism, 9(2), 105-124.

Fennell, D. A., \& Malloy, D. C. (2007). Codes of ethics in tourism: Practice, theory, Synthesis. Clevedon: Channel View Publications.

Fielding, K., Pearce, P. L., \& Hughes, K. (1992), Climbing Ayers Rock: Relating visitor motivation, time perception and enjoyment. Journal of Tourism Studies, 3(2), 49-57.

Frank, R. (1988). Passions within reason: The strategic role of emotions. New York: Norton.

Gazley, B. (2001). Volunteer vacations and what research can tell us about them. E-Volunteerism, 1(2). Retrieved Jan. 2008 from: http://e-volunteerism .com/ win2001/vacintro.html

Gintis, H. (2002). Altrusim and emotions. Behavioral and Brain Sciences, 25, 258-259.

Gray, N. J., \& Campbell, L. M. (2007). A decommodified experience? Exploring aesthetic, economic and ethical values for volunteer ecotourism in Costa Rica. Journal of Sustainable Tourism, 15(5), 463-482.

Griffin, J. (1997). Value judgement: Improving our ethical beliefs. Oxford: Clarendon.

Halpenny, E. A., \& Caissie, L. T. (2003). Volunteering on nature conservation projects: Volunteer experiences, attitudes and values. Tourism Recreation Research, 28(3), 25-33.

Hamilton, W. D. (1964). The genetical evolution of social behaviour (I and II). Journal of Theoretical Biology, 7, 1-52. 
Khalil, E. L. (2004). What is altruism? Journal of Economic Psychology, 25(1), 97-123.

Lepp, A. (2008). Discovering self and discovering others through the Taita Discovery Centre Volunteer Tourism Programme, Kenya. In K. Lyons \& S. Wearing (Eds.), Journeys of discovery in volunteer tourism (pp. 86-100). Wallingford, UK: CABI International.

Lyons, K., \& Wearing, S. (2008a). Journeys of discovery in volunteer tourism. Wallingford, UK: CABI International.

Lyons, K., \& Wearing, S. (2008b). Volunteer tourism as Alternative Tourism: Journeys beyond otherness. In K. Lyons \& S. Wearing (Eds.), Journeys of discovery in volunteer tourism (pp. 3-11). Wallingford, UK: CABI International.

Lyons, K., \& Wearing, S. (2008c). All for a good cause? The blurred boundaries of volunteering and tourism. In K. Lyons \& S. Wearing (Eds.), Journeys of discovery in volunteer tourism (pp. 147-154). Wallingford, UK: CABI International.

Mayr, E. (1988). Toward a new philosophy of biology: Observations of an evolutionist. Cambridge, MA: The Belknap Press.

Matthews, A. (2008). Negotiated selves: Exploring the impact of local-global interactions on young volunteer travellers. In K. Lyons \& S. Wearing (Eds.), Journeys of discovery in volunteer tourism (pp. 101-117). Wallingford, UK: CABI International.

McGehee, N. (2001). Alternative tourism and social movements. Annals of Tourism Research, 29(1), 124-143.

McGehee, N., \& Norman, W. (2002). Alternative tourism as impetus for consciousness raising. Tourism Analysis, 6, 239-251.

McGehee, N., \& Andereck, K. (2008). 'Pettin' the Critters': Exploring the complex relationship between volunteers and the voluntoured in McDowell County, West Virginia, USA, and Tijuana, Mexico. In K. Lyons \& S. Wearing (Eds.), Journeys of discovery in volunteer tourism (pp. 12-24). Wallingford, UK: CABI International.

McGehee, N., \& Santos, C. A. (2005). Social change, discourse and volunteer tourism. Annals of Tourism Research, 32(3), 760-779.

McIntosh, A. J., \& Zahra, A. (2007). A cultural encounter through volunteer tourism: Towards the ideals of sustainable tourism. Journal of sustainable tourism, 15(5), 541-556.

Mowforth, M., \& Munt, I. (2008). Tourism and sustainability: Development, globalization and new tourism in the Third World (3rd ed.). London: Routledge.

Mustonen, P. (2005). Volunteer tourism: Postmodern pilgrimage. Journal of Tourism and Cultural Change, 3(3), 160-177.

Mustonen, P. (2007). Volunteer tourism - Altruism or mere tourism? Anatolia: An international Journal of Tourism and Hospitality Research, 18(1), 97-115.

Myers, B. (2003). The case for volunteerism. Ontario Out of Doors, June, p. 4 
Pearce, P. L. (in press). Tourist behaviour. Clevedon; Buffalo; Toronto: Channel View Publications

Pearce, P. L., \& Lee, U. (2005). Developing the travel career approach to tourist motivation. Journal of Travel Research, 43, 226-237.

Poon, A. (1993). Tourism, technology and competitive strategy. Wallingford, UK: CABI.

Raymond, R. (2008). 'Make a difference!': The role of sending organisations in volunteer tourism. In K. Lyons \& S. Wearing (Eds.), Journeys of discovery in volunteer tourism (pp. 48-62). Wallingford, UK: CABI International.

Ruhanen, L., Cooper, C., \& Fayos-Sola, E. (2008). Volunteering tourism knowledge: A case from the United Nations World Tourism Organisation. In K. Lyons \& S. Wearing (Eds.), Journeys of discovery in volunteer tourism (pp. 25-35). Wallingford, UK: CABI International.

Ryan, C., K. Hughes, \& Chirgwin, S. (2000). The gaze, spectacle and ecotourism. Annals of Tourism Research, 27(1), 148-163.

Scheyvens, R. (2002). Tourism for development: Empowering communities. Harlow: Prentice Hall.

Singh, S., \& Singh, T. V. (2004). Volunteer tourism: New pilgrimages to the Himalayas. In T.V. Singh (Ed.)., New horizons in tourism: Strange experiences and stranger practices (pp. 181-194). Wallingford, UK: CABI.

Simpson, K. (2004). 'Doing development': The Gap Year, volunteer tourists and a popular practice of development. Journal of International Development, 16, 681-692.

Sober, E., \& Wilson, D. S. (1998). Unto others: The evolution and psychology of unselfish behavior. Cambridge, MA: Harvard University Press.

Soderman, N., \& Snead, S. L. (2008). Opening the gap: The motivation of Gap Year travelers to volunteer in Latin America. In K. Lyons \& S. Wearing (Eds.), Journeys of discovery in volunteer tourism (pp. 118-129). Wallingford, UK: CABI International.

Trivers, R. (1971). The evolution of reciprocal altruism. Quarterly Review of Biology, 46, 35-57.

UNWTO technical manual: Collection of Tourism Expenditure Statistics" (1995). World Tourism Organization.. p. 14. http://pub.unwto.org/WebRoot/Store/Shops/ Infoshop/Products/1034/1034-1.pdf. Retrieved 2009-03-26.

Uriely, N., A. Reichel, A., \& Ron, A. (2003). Volunteering in tourism: Additional thinking. Tourism Recreation Research, 28(3), 57-62.

Wallach, M. A., \& Wallach, L. (1983). Psychology's sanction for selfishness: The error of egoism in theory and practice. San Francisco: W. H. Freeman \& Co.

Wearing, S. (2001). Volunteer tourism: Experiences that make a difference. Oxon, UK: CABI Publishing. 
Wearing, S. (2003). Re-centering the self in volunteer tourism. In G. M. S. Dann (Ed.), The tourist as a metaphor of the social world (pp. 237-263). Oxon, UK: CABI.

Wearing, S. (2004). Examining best practice in volunteer tourism. In R. A. Stebbins \& R. T. Graham (Eds.), Volunteering as leisure/Leisure as volunteering. Wallingford, UK: CABI.

Wearing, S., Deville, A., \& Lyons, K. (2008). The volunteer's journey through leisure into the self. In K. Lyons \& S. Wearing (Eds.), Journeys of discovery in volunteer tourism (pp. 63-71). Wallingford, UK: CABI International.

Weber, R.P. (1990). Basic content analysis (2nd ed.). Newbury Park, CA: Sage.

Weiler, B., \& Richins, H. (1995). Extreme, extravagant and elite: A profile of ecotourists on Earthwatch expeditions. Tourism Recreation Research, 20(1), 29-36.

Wight, P. (1993). Ecotourism: Ethics or eco-sell? Journal of Travel Research, 31(3), 3-9.

\section{Appendix}

Basinger, J. (1998). To scientists who use paying volunteers in fieldwork, the benefits outweigh the bother. The Chronicle of Higher Education, 44(41), A14-A15.

Benson, A. (2005). Research tourism: Professional travel for useful discoveries. In M. Novelli (Ed.), Niche tourism: Contemporary issues, trends and cases (pp. 133-144). Amsterdam: Elsevier.

Broad, S. (2003). Living the Thai Life: A case study of volunteer tourism at the Gibbon Rehabilitation Project, Thailand. Tourism Recreation Research, 28(3), 63-72.

Brown, S., \& Morrison, A. (2003). Expanding volunteer vacation participation: An exploratory study on the mini-mission concept. Tourism Recreation Research, 28(3). 73-82.

Brown, S., \& Lehto, X. Y. (2005). Traveling with a purpose: Understanding the motives and benefits of volunteer vacationers. Current Issues of Tourism, 8(6), 479-496.

Callanan, T., \& Thomas, S. (2005). Volunteer tourism: Deconstructing volunteer activities within a dynamic environment. In M. Novelli (Ed.). Niche tourism: Contemporary issues, trends and cases (pp. 182-200). Oxford: ButterworthHeiniman Elsevier.

Campbell, L. M., \& Smith, C. (2006). What makes them pay? Values of volunteer tourists working for sea turtle conservation. Environ Management, 38(1), 373-388.

Coghlan, A. (2005). Towards an understanding of the volunteer tourism experience. Unpublished PhD dissertation, James Cook University, Townsville, Queensland.

Coghlan, A. (2006). Volunteer tourism as an emerging trend or an expansion of ecotourism? A look at potential clients' perceptions of volunteer tourism organisations. International journal of Nonprofit and Voluntary Sector, 11, 225-237.

Coghlan, A. (2007). Towards an integrated image-based typology of volunteer tourism 
organisations. Journal of Sustainable Tourism, 15(3), 267-287.

Cousins, J. A. (2007). The role of UK-based conservation tourism operators. Tourism Management, 28,1020-1030.

Ellis, C. (2003). When volunteers pay to take a trip with scientists-participatory environmental research tourism (PERT). Human Dimensions of Wildlife, 8, 75-80.

Ellis, C. (2003). Participatory environmental research in tourism: A global view. Tourism Recreation Research, 28(3), 45-55.

Gazley, B. (2001). Volunteer vacations and what research can tell us about them. E-Volunteerism, 1(2). Retrieved Jan. 2008 from: http://e-volunteerism .com/ win2001/vacintro.html

Gilmour, J., \& Saunders, D. A. (1995). Earthwatch: An international network in support of research on nature conservation. In D. A. Saunders, J. L. Craig \& E. M. Mattiske (Eds.), Nature Conservation 4: The role of networks (pp. 627-633). Surrey: Beatty \& Sons.

Gray, N. J., \& Campbell, L. M. (2007). A decommodified experience? Exploring aesthetic, economic and ethical values for volunteer ecotourism in Costa Rica. Journal of Sustainable Tourism, 15(5), 463-482.

Halpenny, E. A., \& Caissie, L. T. (2003). Volunteering on nature conservation projects: Volunteer experiences, attitudes and values. Tourism Recreation Research, 28(3), 25-33.

Hartman, J. (1997). The popularisation of science through citizen volunteers. Public Understanding of Science, 5, 69-86.

Lepp, A. (2008). Discovering self and discovering others through the Taita Discovery Centre Volunteer Tourism Programme, Kenya. In K. Lyons \& S. Wearing (Eds.), Journeys of discovery in volunteer tourism (pp. 86-100). Wallingford, UK: CABI International.

Lyons, K. (2003). Ambiguities in Volunteer tourism: A case study of Australians participating in J-1 Visitor Exchange Program. Tourism Recreation Research, 28(3), 5-13.

Lyons, K., \& Wearing, S. (2008a). Journeys of discovery in volunteer tourism. Wallingford, UK: CABI International.

Lyons, K., \& Wearing, S. (2008b). Volunteer tourism as Alternative Tourism: Journeys beyond otherness. In K. Lyons \& S. Wearing (Eds.), Journeys of discovery in volunteer tourism (pp. 3-11). Wallingford, UK: CABI International.

Lyons, K., \& Wearing, S. (2008c). All for a good cause? The blurred boundaries of volunteering and tourism. In K. Lyons \& S. Wearing (Eds.), Journeys of discovery in volunteer tourism (pp. 147-154). Wallingford, UK: CABI International.

Mackney, P., \& Spring, N. (2003). The Earthwatch perspective on volunteers and data validating. www.earthwatch.org/europe/vdvp/millport.html (accessed May 2003)

McDonald, K. (1998). With the help of student volunteers, a marine biologist conducts 
research aimed at saving threatened sharks. The Chronicle of Higher Education, 44(41), A-15-A17.

McGehee, N. (2001). Alternative tourism and social movements. Annals of Tourism Research, 29(1), 124-143.

McGehee, N., \& Norman, W. (2002). Alternative tourism as impetus for consciousness raising. Tourism Analysis, 6, 239-251.

McGehee, N., \& Andereck, K. (2008). 'Pettin' the Critters': Exploring the complex relationship between volunteers and the voluntoured in McDowell County, West Virginia, USA, and Tijuana, Mexico. In K. Lyons \& S. Wearing (Eds.), Journeys of discovery in volunteer tourism (pp. 12-24). Wallingford, UK: CABI International.

McGehee, N., \& Santos, C. A. (2005). Social change, discourse and volunteer tourism. Annals of Tourism Research, 32(3), 760-779.

McIntosh, A. J., \& Zahra, A. (2007). A cultural encounter through volunteer tourism: Towards the ideals of sustainable tourism. Journal of sustainable tourism, 15(5), 541-556.

Mustonen, P. (2005). Volunteer tourism: Postmodern pilgrimage. Journal of Tourism and Cultural Change, 3(3), 160-177.

Raymond, R. (2008). 'Make a difference!': The role of sending organisations in volunteer tourism. In K. Lyons \& S. Wearing (Eds.), Journeys of discovery in volunteer tourism (pp. 48-62). Wallingford, UK: CABI International.

Ruhanen, L., Cooper, C., \& Fayos-Sola, E. (2008). Volunteering tourism knowledge: A case from the United Nations World Tourism Organisation. In K. Lyons \& S. Wearing (Eds.), Journeys of discovery in volunteer tourism (pp.25-35). Wallingford, UK: CABI International.

Singh, S., \& Singh, T. V. (2004). Volunteer tourism: New pilgrimages to the Himalayas. In T.V. Singh (Ed.)., New horizons in tourism: Strange experiences and stranger practices (pp. 181-194). Wallingford, UK: CABI.

Simpson, K. (2004). 'Doing development': The Gap Year, volunteer tourists and a popular practice of development. Journal of International Development, 16, 681-692.

Soderman, N., \& Snead, S. L. (2008). Opening the gap: The motivation of Gap Year travelers to volunteer in Latin America. In K. Lyons \& S. Wearing (Eds.), Journeys of discovery in volunteer tourism (pp. 118-129). Wallingford, UK: CABI International.

Uriely, N., A. Reichel, A., \& Ron, A. (2003). Volunteering in tourism: Additional thinking. Tourism Recreation Research, 28(3), 57-62.

Wearing, S. (2001). Volunteer tourism: Experiences that make a difference. Oxon, UK: CABI Publishing.

Wearing, S. (2003). Re-centering the self in volunteer tourism. In G. M. S. Dann (Ed.), The tourist as a metaphor of the social world (pp. 237-263). Oxon, UK: CABI. 
Wearing, S. (2004). Examining best practice in volunteer tourism. In R. A. Stebbins $\&$ R. T. Graham (Eds.), Volunteering as leisure/Leisure as volunteering. Wallingford, UK: CABI.

Wearing, S., Deville, A., \& Lyons, K. (2008). The volunteer's journey through leisure into the self. In K. Lyons \& S. Wearing (Eds.), Journeys of discovery in volunteer tourism (pp. 63-71). Wallingford, UK: CABI International.

Webb, D. (2002). Investigating the structure of visitor experiences in the Little Sandy Desert, Western Australia. Journal of Ecotourism, 1(2\&3), 149-161.

Weiler, B., \& Richins, H. (1995). Extreme, extravagant and elite: A profile of ecotourists on Earthwatch expeditions. Tourism Recreation Research, 20(1), 29-36. 
Copyright of Annals of Leisure Research is the property of Australian \& New Zealand Association for Leisure Studies Journal and its content may not be copied or emailed to multiple sites or posted to a listserv without the copyright holder's express written permission. However, users may print, download, or email articles for individual use. 